\title{
Pengaruh Perilaku Pemimpin Komitmen Guru terhadap Prestasi Kerja pada MTSN Terusan Kecamatan Muara Bulian
}

\author{
Endang Meliani, Afriantoni \\ Sekolah Tinggi Ilmu Ekonomi Graha Karya, Jurusan Manajemen, Muara Bulian
}

\begin{abstract}
The purpose of this study is to explain the influence of Leaders Behavior and Teacher Commitment to Job Performance in MTs Negeri Terusan Muara Bulian Subdistrict. The analytical method used is quantitative using multiple linear regression analysis tools. The test of significance of influence of Leader Behavior variable $\left(X_{1}\right)$ and Teacher Commitment $\left(X_{2}\right)$ as independent variable, and Work Achievement $(Y)$ as the dependent variable is done T Test and $F$ Test. The result of hypothesis testing on the effect of Leader Behavior and Teacher Commitment to Work Achievement that the value of t arithmetic is 2,139 > from the t table number 2,05183 and the significance level of $(\alpha) 0.05(5 \%)$ it can be seen that this Leader Behavior has influence on Job Performance. The result of hypothesis testing on the basis of the variable Teacher Commitment to Work Achievement that the value of $t$ arithmetic amounted to -1.728 and with a significant level of 5\% obtained t table 2.05183 it can be seen that the value of $t$ arithmetic of $-1.728>$ from number $t$ table 2.05183 and number of significance of 0.05 (5\%) it is known that this Master's Commitment has an effect on Work Achievement. The result of hypothesis test on Lead Behavior variable and Teacher Commitment to Work Achievement showed that $F$ value obtained by $F$ value 2,372 with significance level 0,05 value $f$ table 3,34 this mean that $F$ count $\left(2.372>F\right.$ table $(3,34)$ thus Ho is rejected and Ha accepted, meaning that Leader Behavior $\left(X_{1}\right)$ and Teacher Commitment $\left(\mathrm{X}_{2}\right)$ have a positive effect simultaneously or together on Work Achievement at MTs Negeri Terusan Muara Bulian Subdistrict Adjusted R Square is 0,86. So it can be concluded the percentage of influence of Leaders Behavior and Teacher Commitment to Job Performance in MTs Negeri Terusan of $0.86 \%$ and $91.4 \%$ in influencing other variables not examined in this study.
\end{abstract}

Keywords: Influence Leader Behavior, Teacher Commitment, Work Achievement at MTs Negeri Terusan Muara Bulian Subdistrict.

\section{PENDAHULUAN}

Pendidikan merupakan hal yang sangat penting karena pendidikan salah satu penentu mutu Sumber Daya Manusia. Dimana keunggulan suatu bangsa tidak lagi ditandai dengan melimpahnya kekayaan alam, melainkan pada keunggulan Sumber Daya Manusia (SDM). Dimana mutu Sumber Daya Manusia (SDM) berkorelasi positif dengan mutu pendidikan. Mutu pendidikan sering diindikasikan dengan kondisi yang baik, memenuhi syarat, dan segala komponen yang harus terdapat dalam pendidikan. Komponen-komponen tersebut adalah masukan, proses, keluaran, tenaga kependidikan, sarana dan prasarana, serta biaya.

Menjadi tenaga kependidikan yang profesional tidak akan terwujud begitu saja tanpa adanya upaya untuk meningkatkannya, adapun salah satu cara untuk mewujudkannya adalah dengan pengembangan profesionalisme. Ini membutuhkan dukungan dari pihak yang mempunyai peran penting, dalam hal ini adalah kepala sekolah, dimana kepala sekolah merupakan pemimpin pendidikan yang sangat penting karena kepala sekolah berhubungan langsung dengan pelaksanaan program pendidikan di sekolah. Kepemimpinan merupakan fenomena universal yang sangat penting dalam organisasi, baik organisasi bisnis, pendidikan, politik, keagamaan, maupun sosial.

Hal ini disebabkan dalam proses interaksi untuk mencapai tujuan, orang-orang ada didalamnya membutuhkan seseorang yang dapat mengkoordinasikan, mengarahkan, dan memudahkan orang-orang tersebut untuk mencapai tujuan, baik tujuan individu maupun tujuan organisasi. Tanpa kepemimpinan suatu organisasi hanyalah sejumla orang atau mesin yang mengalami kebingungan.

Ketercapaian tujuan pendidikan sangat bergantung pada kecakapan dan kebijaksanaan kepemimpinan kepala sekolah yang merupakan salah satu pemimpin pendidikan. Karena kepala sekolah merupakan seorang pejabat yang profesional dalam organisasi sekolah yang bertugas mengatur semua sumber organisasi dan bekerjasama dengan guru-guru dalam mendidik siswa untuk mencapai tujuan pendidikan.

Dengan keprofesionalan kepala sekolah ini, pengembangan profesionalisme tenaga kependidikan mudah dilakukan karena sesuai dengan fungsinya, kepala sekolah memahami kebutuhan sekolah yang ia pimpin sehingga kompetensi guru atau komitmen guru tidak kompetensi yang ia miliki sebelumnya, melainkan bertambah dan berkembang dengan baik sehingga profesionalisme guru akan terwujud. Karena tenaga kependidikan profesional tidak hanya menguasai bidang ilmu, bahan ajar, dan metode yang tepat, akan tetapi mampu memotivasi peserta didik, memiliki keterampilan yang tinggi dan wawasan yang luas terhadap dunia pendidikan.

Menurut Sedarmayanti (2011) komitmen guru sebagai kekuatan bathin yang datang dari dalam hati seorang guru dan kekuatan dari luar itu sendiri tentang tugasnya yang dapat memberi pengaruh besar terhadap 
sikap guru berupa tanggung jawab terhadap perkembangan ilmu pengetahuan dan teknologi.

Untuk itu komitmen guru harus dilakukan secara tersadar sebagai seorang guru dan dapat melahirkan tangguang jawab yang dapat mengarahkan serta membimbing dalam kegiatan pembelajaran.

Prestasi kerja merupakan suatu hasil yang kerja yang dicapai dari seseorang dalam melaksanakan tugas yang dibebankan kepadanya. Masalah kepuasan kerja harus mendapat perhatian yang serius bagi setiap organisasi, bila kepuasan kerja tercapai pegawai dapat bekerja dengan optimal yang tentunya akan membawa dampak pada pencapaian organisasi maupun prestasi sekolah secara keseluruhan yang selanjutnya akan meningkatkan kinerjanya bagi organisasi atau sekolah.

Suatu hal yang cukup jelas memberikan informasi adanya perbedaan prestasi kerja antar individu adalah perbedaan kemampuan dan keterampilan yang dimiliki oleh setiap individu. kemampuan dan keterampilan individu juga sangat tergantung pada kemampuan intelektual, bakat dan pengalaman yang berbeda-beda. Untuk mengatasi kekurangan pada faktor ini maka banyak instansi pemerintah yang mengadakan sistem seleksi, training dan sosialisasi informasi yang sesuai.

Hal lain yang dipertimbangkan adalah unsur motivasi atau dorongan yang ada pada diri individu untuk berperilaku termasuk bagaimana meningkatkan prestasi kerjanya. Motivasi yang ada pada seseorang ini akan mempengaruhi apakah dia akan mengerjakan setiap tugasnya dengan baik atau sebaliknya. Individu dengan motivasi berprestasi tinggi di harapkan mampu memperlihatkan prestsi kerja yang relatif lebih tinggi dibandingkan dengan individu yang memiliki apakah masalah tertentu dianggap sebagai penghambat atau tantangan untuk menghadapinya.

\section{Tinjauan Pustaka}

\section{Manajemen Sumber Daya Manusia}

Keberhasilan suatu perusahaan tentu suatu manajemen yang baik serta pengelolaan yang terorganisis, berikut beberapa definisi pengertian Manajemen Sumber Daya Manusia menurut para ahli :

Menurut Edy Sutrisno (2009) manajemen sumber daya manusia adalah kegiatan perancanaan, pengadaan, pengembangan, pemeliharaan, serta penggunaan SDM untuk mencapai tujuan baik secara individu maupun organisasi.

Menurut Sedarmayanti (2011) manajemen sumber daya manusia adalah kebijakan dan praktik menetukan aspek manusia atau sumber daya manusia dalam posisi manajemen, termasuk merektut, menyaring, melatih, memberi penghargaan dan penilaian.

Menurut Tjutju Yuniarsih dan Suwatno (2009) manajemen sumber daya manusia adalah bagian dari ilmu manajemen yang memfokuskan perhatiannya pada peraturan peranan sumber daya manusia dalam kegiatan suatu organisasi.
Dari uraian diatas dapat dapat ditarik kesimpulan bahwa manajemen sumber daya manusia adalah suatu ilmu atau cara bagaimana mengatur hubungan dan peranan sumber daya manusia (tenaga kerja) yang dimiliki oleh individu secara efesien serta dapat digunakan secara maksimal sehingga tercapai suatu tujuan dan suatu proses pendayagunaan manusia sebagai tenaga kerja secara manusiawi agar potensi fisik dan fisikis yang dimiki berfungsi maksimal bagi pencapaian tujuan organisasi (perusahaan).

\section{Fungsi Manajemen Sumber Daya Manusia}

Fungsi Manajemen Sumber Dya Manusia terdiri dari :

1. Planning atau cara perancanaan yaitu proses menentukan terlebih dahulu program personalia yang akan membantu mencapai tujuan sekolah yang telah ditetapkan.

2. Organizing atau pengorganisasian yaitu setelah apa yang telah di putuskan maka perlu di buat organisasi untuk melaksanakannya jika sekolah telah menentukan fungsi-fungsi yang harus di jalankan oleh para pegawai maka manajemen personalia harusla membentuk organisasi dengan merancang susunan dari berbagai hubungan antara jabatan, personalia dan faktor-faktor fisik.

3. Actuating/Directing atau pengarahan yaitu mengusahakan agar pegawai mau melaksanakan pekerjaannya tersebut ( di lakukan setelah fungsi perancanaan dan fungsi pegorganisasian ).

4. Controlling atau pengawasan yaitu suatu fungsi dari manajemen personalia untuk mengamati dan membandingkan pelaksanaan dengan rencana dan mengoreksinya apabila terjadi penyimpangan.

\section{Perilaku Pemimpin}

Dalam mengembangkan dan memajukan suatu organisasi manajer dengan pengaruh kepemimpinan yang dimilikinya berkewajiban untuk memahami perilaku setiap karyawan yang berada di lingkungan kerjanya.karena itu dalam mewujudkan suatu perilaku yang diinginkan oleh konsep manajemen maka seorang manajer mengharuskan untuk mempergunakan kekuatannya.

Menurut Irham Fahmi (2013) adalah Perilaku Pemimpin adalah Seseorang dalam melaksanakan pekerjaan tidak hanya harus dilakukan atas dasar perintah dan sanksi yang di terima. Namun seorang pemimpin juga harus mengedepankan sikap bawahan yang teraplikasi dalam bentuk personal power yang dimiliki.

Menurut Dewi Hanggraeni (2011) Perilaku Pemimpin adalah bagaimana kita mempengaruhi perilaku manusia baik dalam diri sesorang maupun dalam lingkungan sekitar. Jikat tingkat kepemimpinan rendah, maka kemungkinan kepemimpinannya akan lemah. 
Dari Teori ini berioentasi pada cara perilaku yang dilakukan oleh seorang pemimpin untuk memperlakukan pengikutnya dalam upaya mempengaruhi perilaku bawahan. Pada teori perilaku, memandang bahwa keberhasilan kepemimpinan lebih banyak tergantung perilaku (bahavior), keterampilan (skills), dan tindakan (action) pemimpin dan kurang tergantung pada sifat-sifat pribadi. Karena keterampilan dan perilaku dapat dipelajari dan diubah, semantara banyak sifat adalah relatif tidak berubah atau tetap. Ketiga keterampilan yang pemimpin gunakan adalah technikal skiils (keterampilan teknis), human skills (keterampilan kemanusiaan) dan conceptual skills (keterampilan konseptual). Meskipun ketiga keterampilan itu saling memiliki keterkaitan atau hubungan dlam praktik, mereka dapat dipahami secara terpisa.

1. Technical skills mengacu kepada pengetahuan dan kemampuan seseorang dalam jenis proses dan teknik apapun. Technical skills merupakan segi yang membedakan performasi kerja (job performance) pada level operasi/pelaksanaan dan keahlian, tetapi ketika karyawan dipromasikan ke tingkat tanggung jawab kepemimpinan, keterampilan teknis mereka menjadi secara profesional berkurang kepentingannya atau berkurang maknanya. Sebagai manajer, mereka semakin tergantung pada keterampilan teknis para bawahannya, dalam banyak kasus mereka belum pernah mempraktikkan beberapa keterampilan teknis yang mereka sepurvisi.

2. Human skills adalah kemampuan untuk bekerja sama dengan orang lain secara efektif dan untuk membangun teamworks (kerja tim). Tidak ada pemimpin pada tingkat organisasi manapun terhindar dari persyaratan untuk memiliki keterampilan human skills. Human skills merupakan bagian aktivitas terbesar dari perilaku pemimpin.

3. Conceptual skills adalah kemampuan untuk berfikir dari segi model, kerangka kerja, dan persahabatan yang luas, seperti perancanaan jangka panjang. Semakin tinggi tingkat pekerjaan manajerial akan semakin membutuhkan kemampuan conceptual skills. Conceptual skills berhubungan dengan kerjasama dan interaksi dengan orang, semanatra technical skills berkaitan dengan keterampilan mengerjakan dan memanfaatkan barang.

\section{Tipologi Kepemimpin}

Dari uraian tentang tipologi kepemimpin, sebagai bagian intergal dari perkara-perkara yang terkait dengan masalah kepemimpinan secara keseluruhan. Sebenarnya sangat bervariasi, pendapat dan tinjauan tentang tipologi kepemimpinan tersebut, namun untuk baiknya dibatasi untuk tujuh tipologi saja, yaitu

1. Kepemimpinan tradisional;

2. Kepemimpinan kharismatik;

3. Kepemimpinan rasional;

4. Kepemimpinan otoriter;
5. Kepemimpinan demokratis;

6. Kepemimpinan tunggal;

7. Kepemimpinan kolektif;

Kembali pada pembicaraan tentang tipologi kepemimpinan yang telah diungkapkan seperti tujuh macam diatas, dapat diuraiakan sebagai berikut.

\section{Komitmen Guru}

Guru memiliki tugas yang beragam yang berimplementasi dalam bentuk pengabdian. Tugas tersebut meliputi bidang profesi, bidang kemanusiaan dan bidang kemasyarakatan. Tugas guru sebagai profesi meliputi mendidik, mengajar, dan melatih. Mendidik berarti meneruskan dan mengembangkan ilmu pengetahuan dan teknologi. Sedangkan melatih berarti mengembangkan keterampilan-keterampilan pada siswa. Dari permasalah ini dapat melihat apakah seorang guru termasuk dalam tenaga pendidik profesional, karena sekarang ini peningkatan mutu pendidikan yang secara langsung dapat dikaitkan dengan pengetahuan tentang wawasan dan kebijakan pendidikan, teori belajar dan pembelajaran, evaluasi pembelajaran, serta tekhnologi informasi dan komunikasi.

\section{Pengertian Komitmen Guru}

Komitmen Guru memiliki berbagai macam pengertian, antara lain sebagai berikut :

Menurut Sedarmayanti (2011) komitmen guru adalah kekuatan bathin yang datang dari dalam hati seorang guru dan kekuatan dari luar itu sendiri tentang tugasnya yang dapat memberi pengaruh besar terhadap sikap guru berupa tanggung jawab terhadap perkembangan ilmu pengetahuan dan teknologi.

Menurut fachruddin dan Ali Idrus (2009) komitmen guru adalah peningkatan mutu pendidikan dan mereka berada di titik sentral dari setiap usaha reformasi pendidikan yang diarahkan pada perubahan-perubahan kualitatif.

Menurut Oemar hamalik (2010) komitmen guru adalah pembuatan keputusan dalam pembinaan kurikulum bukan saja menjadi tanggung jawab para perancana, akan tetapi juga menjadi tanggung jawab para guru disekolah.

Dari definisi di atas dapat disimpulkan bahwa komitmen guru adalah suatu keterkaitan antara diri dan tugas yang dilakukan secara tersadar sebagai seorang guru dan dapat melahirkan tangguang jawab yang dapat mengarahkan serta membimbing dalam kegiatan pembelajaran.

\section{Macam-macam Komitmen Guru Komitmen Terhadap Sekolah}

Sekolah adalah lembaga sosial yang tumbuh dan berkembang untuk masyarakat. Sebagai lembaga sosial formal tersebut merupakan suatu organisasi yaitu terikat terhadap tata aturan formal yang dimiliki program atau target atau sasaran yang jelas serta struktur 
kepemimpinan penyelenggaraan atau pengelolaan yang resmi, dalam perkembangan kepribadian anak didik, peranan sekolah dengan melalui kurikulum, antara lain sebagai berikut :

a.) Anak didik belajar bergaul sesama anak didik, antara guru dengan anak didik, dan anata didik dengan karyawan.

b.) Anak didik belajar menaati perturan sekolah.

c.) Mempersiapkan anak didiknya menjadi anggota masyarkat yang berguna bagi agama, bangsa dan negara.

\section{Komitmen Terhadap Kegiatan Akademik}

Seorang guru yang mempunyai komitmen akan menyiapkan waktu untuk melaksankan tugas yang berkaitan dengan pembelajaran seperti :

a.) Merencanakan program belajar mengajar.

b.) Melaksanakaan /mengelola proses belajar mengajar.

c.) Menilai kemajuan proses belajar mengajar.

d.) Menguasai bahan pelajaran dalam pengertian menguasai bidang studi atau mata pelajaran yang dipegangnya.

Adapun tugas guru dengan komitmen terhadap kegiatan akademik sekolah antara lain :

a.) Guru sebagai perancang pembelajaran.

b.) Guru sebagai pengelola pembelajaran.

c.) Guru sebagai pengarah pembelajaran.

d.) Guru sebagai pelaksana kurikulum dan evaluator.

\section{Komitmen Terhadap Siswa-siswi}

Seorang guru harus mengetahui perbedaan dari siswa-siswi dalam membangun komitmen dan kesadaran bagi pelajar atau individu. Berikut perbedaan dalam membangun komitmen kesadaran bagi pelajar atau individu antara lain: Perbedaan dalam latar belakang;

a.) Perbedaan dalam kesehatan dan nutrisi;

b.) Perbedaan dalam kemampuan anak di sekolah;

c.) Perbedaan dalam minat.

\section{Komitmen Untuk Menciptakan Pengajaran Bermutu}

Seorang guru senantiasa merespon perubahanperubahan pengetahuan dan ide-ide dalam implementasi kurikulum di kelas. Sehingga mutu pembelajaran atau mutu pendidikan akan dapat dicapai jika guru memenuhi kebutuhan siswa-siswi dan yang harus dipersiapkan oleh guru, Kemampuan guru menciptakan pembelajaran yang aktif dan menyenangkan adalah upaya positif untuk meningkatkan mutu pembelajaran.

\section{Komitmen Dalam Peningkatan Kinerja Guru Profesional}

Guru merupakan kunci dalam peningkatan mutu pendidikan dan mereka berada dititik sentral dari setiap usaha reformasi pendidikan yang diarahkan pada perubahan-perubahan kualitatif. Setiap usaha peningkatan mutu pendidikan seperti perubahan kurikulum, pengembangan metode-metode mengajar, penyediaan sarana akan berarti apabila melibatkan guru.

Adapapun pengembangan standar kompetensi guru ditunjukan pada peningkatan profesionalisme guru dan pembinaan karir secara terstrukrur.

\section{Pendidik Sebagai Profesi}

Kategori profesi apabila memenuhi syarat-syarat antara lain:

a.) Didasarkan atas sosok ilimu pengetahuan teoritis (body of theoretical knowledge) yang disepakati bersama.

b.) Komitmen untuk menerapkan pengetahuan dan keterampilan dalam praktek secara otonomi dan berkuatan monopoli.

c.) Adanya kode etik profesi sebagai instrumen untuk memonitir tingkat ketaatan anggotanya dan sistem sanksi yang diperlukan.

d.) Adanya organisasi profesi yang mengembangkan, menjaga, dan melindungi profesi.

e.) Sistem sertifikasi bagi individu yang memiliki pengetahuan dan keterampilan untuk dapat menjalankan profesi tersebut.

\section{Peningkatan Kinerja Profesional Guru}

1. Akuntabilitas publik

Otonomi dalam pengelolaan guru seharusnya lebih fleksibel dimana kompensasi yang diterima guru tidak mengacu kepada sistem kompensasi PNS. Nilai didasarkan pada prestasi kerja dalam kurun waktu guru mempertahankan kinerja prima. Sistem rekrutmen guru lebih terfokus pada profesionalisme tanpa mengenai persyaratan batas usia, jenis kelamin, asal perguruan tinggi, dan sebagainya.

2. Pengembangan Total Quality Management dalam Pendidikan.

Implementasi Total Quality Management dibidang pendidikan secara fungsional dalam struktur organisasi lembaga pendidikan secara fungsional dalam struktur organisasi lembaga pendidikan terbagi tiga tingkatan, yaitu: (1) quality control, diperankan oleh guru sebagai lini terdepan pelaksanaan proses pembelajaran: (2) quality assurance, dijalankan oleh para pemimpi. Menengah yang dalam hal ini adalah tingkat jurusan/prodi; dan (3) quality management adalah merupakan tanggung jawab pucuk pimpinan organisasi.

3. Pengembangan Profesionalisme Guru (Tenaga Pendidik).

Ilmu pendidikan sebagai roh pengembangan profesi pendidikan mengkaji dan membersihkan pemahaman bagaimana tugas dan fungsi, serta perilaku pendidik yang profesional dalam menciptakan suasana layanan pembelajaran yang mendidik dan menyenangkan.

4. Kompetensi dan Keterampilan Profesional Guru.

Kompetensi merupakan kemampuan personal yang di perlukan pada suatu profesi tertentu berupa: 
pengetahuan, keterampilan, sakap, nilai perilaku, dan kemampuan manegerial. Guru sebagai profesi secara umum dipersyaratkan empat gugus kompetensi, yaitu

(1) mendidik, (2) mengajar, (3) melatih, dan (4) membimbing. Secara operasional, keterampilan perilaku profesi keguruan terwujud dalam bentuk tindakan atau perilaku pendidik/guru dalam berkomunikasi dengan peserta didik baik berupa kata-kata maupun dalam bentuk bahasa tubuh. Berikut ini dikemukanan beberapa keterampilan perilaku profesional keguruan yang sangat esensial berlangsung dalam proses pembelajaran :
a.) Keterampilan menyapa.
b.) Keterampilan menyuruh.
c.) Keterampilan marah.
d.) Keterampilan menghukum, dan
e.) Keteampilan memotivasi.

\section{Prestasi Kerja}

Prestasi Kerja adalah hasil kerja yang secara kualitas dan kuantitas yang dicapai oleh seseorang pegawai dalam melaksanakan tugasnya sesuai dengan tanggung jawab diberikan kepadanya. Menurut Edy Sutrisno (2009) Prestasi keja adalah sebagai hasil yang telah dicapai seseoarang dari tingkah laku kerjanya dalam melaksanakan aktivitas kerjanya melalui proses yang panjang yaitu proses penilaian prestasi kerja karyawan yang disebut dengan istilah permonce apparaisal.

Menurut Anwar Prabu Mangkunegara (2012) prestasi kerja adalah hasil kerja secara kualitas dan kuantitas yang dicapai oleh seorang pegawai dalam melaksanakan tugasnya sesuai dengan tanggung jawab yang diberikan kepadanya.

Dari uraian diatas dapat di simpulkan prestasi kerja pada dasarnya merupakan salah satu factor kunci guna mengembangkan suatu sekolah secara efektif dan efesien, kareana adanya kebijakan atau program penilaian prestasi kerja berarti sekolah telah memanfaatkan secara baik sumber daya yang ada dalam organisasi.

\section{Penilaian Prestasi Kerja}

Penilaian prestasi kerja merupakan proses dimana dalam organisasi-organisasi mengevaluasi atau menilai prestasi kerja para pegawai. Berikut beberapa para ahli yang mengemukakan mengenai penilaian prestasi kerja para pegawai :

Menurut Sedarmayanti (2011) penilaian prestasi kerja adalah menilai rasio kerja yang dengan standar kualitas maupun kuantitas yang dihasilkan setiap para pegawai suatu pendekatan dalam melakukan penilaian prestasi kerja para pegawai atau karyawan.

Berdasarkan pendapat diatas, penilaian prestasi kerja pegawai adalah suatu proses penilaian prestasi kerja pegawai yang dilakukan pemimpin perusahaan secara sistematik berdasarkan pekerjaan yang ditugas kepadanya.

Yang menilai prestasi kerja pegawai, yaitu atasan pegawai langsung, dan atasan tak langsung. Disamping itu pula, kepala bagian personalia berhak pula memberikan penilaian prestasi terhadap semua pegawainya sesuai dengan data yang ada dibagian personalia.

\section{Kegunaan Penilaian Prestasi Kerja} berikut :

Kegunaan penilaian prestasi kerja adalah sebagai

1. Perbaikan Prestasi Kerja

Umpan balik pelaksanaan kerja memungkinkan pegawai, manejer dan departemen personalia dapat membetulkan kegiatan-kegiatan mereka untuk memperbaiki prestasi.

2. Penyesuain-penyesuaian Kompensasi

Evaluasi dan prestasi kerja membantu para pengambil keputusan dalam menentukan kenaikan upah, pemberian bonus, dan bentuk kompensasi lainnya.

3. Perancanaan dan pengembangan karir

Umpan balik prestasi mengarahkan keputusankeputusan karir, yaitu tentang jalur karir tertentu yang harus di teliti.

\section{METODE PENELITIAN Jenis Penelitian}

Jenis penelitian ini adalah metode penelitian kuantitatif, yang menjadi objek penelitian adalah MTS Negeri Terusan, Kecamatan Muara Bulian yang berolakasi di jalan Simpang Terusan Kecamatan Muara Bulian Kabupaten Batang Hari. Selanjutnya yang menjadi subjek merupakan Pemimpin dan pegawai di lingkungan MTS Negeri Terusan Kecamatan Muara Bulian Kabupaten Batang Hari tersebut.

\section{Jenis dan Sumber Data Penelitian Jenis Data}

Menurut Arikunto (2010), data penelitian menurut jenis ada dua:

1) Data Kualitatif adalah data yang bukan dalam bentuk angka atau tidak dapat dihitung dalam bentuk bilangan riil, dan diperoleh dari hasil wawancara dengan pimpinan objek penelitian (dalam hal ini MTS Negeri Terusan) dan pegawai serta berbagai informasi yang diperoleh dari pihak lain yang berkaitan dengan penelitian.

2) Data kuantitatif adalah data yang diperoleh dalam bentuk angka-angka yang memiliki suatu hitung baku secara matematis, yang diperoleh dari proses kegiatan penelitian.

\section{Sumber Data}

Masih menurut supranto (2010), Sumber data yang digunakan dalam penelitian ini terdiri dari dua macam yaitu data primer dan data sekunder. 
1) Data primer adalah data yang diperoleh penulis melalui observasi atau pengamatan langsung dari lokasi objek penelitian dan lingkungan sekitar, baik itu melalui observasi, Kuesioner dan wawancara secara langsung dengan pimpinan dan pegawai serta pihak luar yang sesuai dengan kebutuhan dalam penelitian ini.

2) Data Sekunder adalah data yang diperoleh secara tidak langsung, yaitu data yang tersebut diperoleh penulis dari dokumen-dokumen instansi (dalam hal ini MTS Negeri Terusan, Kecamatan Muara Bulian) dan buku-buku literatur yang memberikan infomasi tentang Periku Pemimpin, Komitmen guru, dan prestasi kerja dalam Peningkatan Mutu Pendidikan.

\section{Metode Pengumpulan Data Penelitian Penelitian Kepustakaan dan Teoritis}

Merupakan upaya untuk mengumpulkan data sekunder dari instansi yang diteliti, landasan teori dan informasi yang berkaitan dengan penelitian ini dengan cara dokumentasi. Studi dilakukan antara lain dengan mengumpulkan data yang bersumber dari literaturliteratur, bahan kuliah, dan hasil penelitian lainnya yang ada hubunganya dengan objek penelitian. Hal ini dilakukan untuk mendapatkan tambahan pengetahuan mengenai masalah yang sedang diteliti.

\section{Studi lapangan}

Studi Lapangan merupakan upaya penulis mengumpulkan data faktual atau aktual yang diperlukan dengan cara melakukan pengamatan langsung pada instansi yang menjadi objek penelitian, baik melalui observasi, penyebaran kuesioner kepada para pegawai dan ataupun wawancara.

Penelitian Lapangan dilakukan dengan cara :

1) Interview, merupakan metode untuk mendapatkan data dengan cara melakukan tanya jawab secara langsung dengan pihak-pihak yang bersangkutan guna mnendapatkan data dan keterangan yang menunjang.

2) Observasi, adalah teknik pengumpulan data dengan cara melakukan pengamatan langsung pada objek yang diteliti sehingga diperoleh gambaran yang jelas mengenai masalah yang dihadapi.

3) Kuesioner, adalah pengumpulan data dengan cara menyebarkan daftar pertanyaan kepada responden yang dijadikan sebagai sampel penelitian. Kuesioner menggunakan skala likert, skala Likert digunakan untuk mengukur sikap, pendapat, dan persepsi seseorang atau sekolompok orang tentang fenomena sosial. Sehingga untuk mengetahui pengukur jawaban responden pada penelitian ini yang mana menggunakan instrumen penelitian berupa kuisioner, penulis menggunakan metode skala likert (Likert's summated Ratings). Dalam pengukuran jawaban responden, pengisian kuesioner diukur dengan menggunakan likert, dengan tingkatan berikut : a) Jawaban Sangat setuju diberi bobot 5

b) Jawaban Setuju diberi bobot 4

c) Jawaban Ragu-ragu diberi bobot 3

d) Jawaban Tidak setuju diberi bobot 2

e) Jawaban Sangat Tidak Setuju diberi bobot 1

\section{Populasi dan Sampel Penelitian}

Riduwan (2012) mengemukakan bahwa populasi adalah wilayah generalisasi yang terdiri atas objek atau subjek, yang mempunyai kualitas dan karakteristik tertentu yang diterapkan oleh peneliti untuk dipelajari dan kemudian ditarik kesimpulannya. Sedangkan sampel, menurut Riduwan (2012) adalah bagian respresentif dari jumlah dan karakteristik yang dimiliki oleh populasi.

\section{Penentuan Jumlah Populasi}

Dalam penelitian ini, jumlah populasi sebanyak 30 orang yang terdiri dari 2 orang unsur pimpinan, 26 orang guru dan staf tata usaha, 1 orang pelayan, dan 1 orang satpam atau penjaga.

\section{Penentuan Jumlah Sampel}

Dalam penelitian ini jumlah sampel di tentukan dengan metode. Riduwan (2012) Diterangkan bahwa jika populasi lebih dari 100, maka untuk sampel diambil $10-15 \%$ atau $20-25 \%$ dari jumlah populasi. Tapi jika populasi dibawah 100, maka keseluruhan populasi dijadikan sampel, di karenakan populasi dalam penelitian ini sebanyak 30 orang maka seluruh populasi di jadikan sampel. Jadi jumlah sampel dalam penelitian ini sebanyak 30 orang.

\section{Lokasi}

Lokasi penelitian yaitu di MTS Negeri Terusan, Desa Pasar Terusan Rt.10 Kecamatan Muara Bulian, Kabupaten Batang Hari.

\section{Teknik Pengukuran Data}

Untuk mendapatkan data mengenai Pengaruh Perilaku Pemimpin Dan komitmen Guru Terhadap Prestasi Kerja dalam Peningkatan Mutu Pendidikan Pada MTS Negeri Terusan, Kecamatan Muara Bulian, maka kuesioner di sebarkan kepada responden untuk mengukur persepsi responden di gunakan skala likert yang memiliki tingkat preferensi jawaban yang masingmasing mempunyai skala 1-5 dengan rincian sebagai berikut :

1. Nilai 1 : Sangat Tidak Setuju (STS)

2. Nilai 2 : Tidak Setuju (TS)

3. Nilai $3: \operatorname{Netral}(\mathrm{N})$

4. Nilai 4 : Setuju (S)

5. Nilai 5 : Sangat Setuju (SS)

\section{Metode Analisis}

Analisis deskriptif kuantitatif merupakan metode yang bertujuan mengubah kumpulan data mentah 
menjadi bentuk yang mudah dipahami, dalam bentuk infomasi yang ringkas, dimana hasil penelitian beserta analisanya di uraikan dalam suatu tulisan ilmiah yang mana dari analisa tersebut akan dibentuk suatu kesimpulan.

Pada penelitian yang menggunakan sejumlah Responden (populasi atau sampel) sebagai sumber data, maka data yang akan terkumpul menjadi bilangan yang besar, bila dirata-ratakan (menggunakan sistem indeks) akan menghasilkan data dalam bentuk pecahan atau bilangan berkomah, maka untuk mempermudah penafsirannya diperlukan bantuan rentan skala indeks. Cara yang dapat digunakan ialah metode intervalisasi data (tabel distribusi frekuensi) dengan langkah sebagai berikut :

1. Menentukan jumlah kelas interval (dinotasikan $\mathrm{k}$ ), dimana jumlah kelas dalam penelitian ini ada 5 (lima kelas diantaranya SS, S, N, TS, STS).

2. Menentukan rentang data hasil observasi (Range dinotasikan R), dimana $\mathrm{R}=$ Nilai Observasi Terbesar - Nilai Obsevasi Terkecil, dalam penelitian ini, Nilai Observasi Terbesar $=5(\mathrm{SS})$ dan Nilai Obsevasi Terkecil $=1$ (STS), sehingga $\mathrm{R}=5-1=4$.

3. Menentukan panjang kelas tiap interval (Pk), dimana: $\mathrm{Pk}=\frac{\mathrm{R}}{\mathrm{k}}=\frac{4}{5}$

$\mathrm{Pk}=0,8$

\section{Alat Analisis}

\section{1) Uji Validitas dan Reliabilitas Instrumen}

Instrumen penelitian (kuisioner) yang baik harus memenuhi persyaratan yaitu valid dan reliabel. Untuk mengetahui validitas dan reliabilitas kuesioner perlu dilakukan pengujian atas kuisioner dengan menggunakan uji validitas dan uji reliabilitas.

a) Uji reliabilitas dimaksudkan untuk mengukur suatu kuisioner yang merupakan indikator dari variabel. Realibiltas diukur dengan uji statistik cronbach's alpha $(\alpha)$. Suatu variabel dikatakan reliabel jika memberikan nilai cronbach' alpha> 0,50 .

b) Uji validitas digunakan dengan untuk mengukur sah atau valid tidaknya suatu kuissioner. Uji validitas dilakukan dengan melakukan korelasi bivarate antara masing-masing skor indikator dengan total skor variabel.

\section{2) Analisis Regresi Linear Berganda}

Analisis regresi linear berganda digunakan untuk mengetahui hubungan dan pengaruh antara Perilaku Pemimpin dan Kominmen Guru terhadap Prestasi Kerja Guru dalam Peningkatan Mutu Pendidikan. Untuk menguji variabel tersebut maka digunakan analisa regresi linear berganda dengan rumus sebagai berikut :

\section{$Y=a+b_{1} X_{1}+b_{2} X_{2}+e$}
Dimana :
$\mathrm{Y}=$ Prestasi Kerja
a $=$ Konstanta
$b_{1} X_{1}=$ Koefesien Regresi
$\mathrm{X} 1=$ Perilaku Pemimpin
$\mathrm{X} 2$ =Komitmen Guru
e $=$ Probabilitas error

\section{3) Uji t (Uji Terpisah/Persial)}

Uji ini digunakan untuk mengetahui apakah masing-masing variabel bebasnya secara sendirisendiri berpengaruh secara signifikan terhadap variabel terikatnya. Dimana $\mathrm{t}_{\text {tabel }}>\mathrm{t}_{\text {hitung }}, \mathrm{H}_{0}$ diterima. Dan jika $t_{\text {tabel }}<t_{\text {hitung }}$, maka $\mathrm{H}_{\mathrm{a}}$ diterima, begitupun jika sig $>\alpha(0,05)$, maka $\mathrm{H}_{0}$ diterima $\mathrm{H}_{\mathrm{a}}$ ditolak dan jika $\mathrm{sig}<\alpha(0,05)$ maka $\mathrm{H} 0$ ditolak $\mathrm{H}_{1}$ diterima.

\section{4) Uji f (Uji Serempak/Simultan)}

Uji ini digunakan untuk mengetahui pengaruh bersama-sama variabel bebas terhadap variabel terikat. Dimana $\mathrm{f}_{\text {hitung }}>\mathrm{f}_{\text {tabel }}$, maka $\mathrm{H}_{\mathrm{a}}$ diterima atau secara bersama-sama variabel bebas dapat menerangkan variabel terikatnya secara serentak. Sebaliknya apabila $\mathrm{f}_{\text {hitung }}<\mathrm{f}_{\text {tabel }}$, maka $\mathrm{H}_{0}$ diterima atau secara bersama-sama variabel bebas tidak memiliki pengaruh terhadap variabel terikat. Untuk mngetahui signifikan atau tidak pengaruh secara bersama-sama variabel bebas terhadap variabel terikat maka digunakan probability sebesar $5 \%(\alpha=0,05)$

a) jika sig $>\alpha(0,05)$, maka $\mathrm{H}_{0}$ diterima $\mathrm{H}_{\mathrm{a}}$ ditolak.

b) jika sig $<\alpha(0,05)$, maka $\mathrm{H}_{0}$ ditolak $\mathrm{H}_{\mathrm{a}}$ diterima.

\section{5) Analisis Koefisien Determinasi}

Koefesien Determinasi pada intinya mengukur seberapa jauh kemampuan model dalam menerangkan variasi variabel terikat. Nilai koefesien determinasi adalah $0<\mathrm{R}<1$. Nilai $\mathrm{R}$ yang kecil berarti kemampuan variabel-variabel independen dalam menjelaskan variasi variabel dependen amat terbatas. Nilai yang mendekati satu berarti variabel-variabel independen memberikan hampir semua informasi yang dibutuhkan untuk memprediksi variabel dependen. Kelemahan mendasar penggunaan koefesien determinasi adalah biasanya terhadap jumlah variabel independen yang dimasukan ke dalam model. Setiap tambahan satu variabel independen ke dalam model, maka $R$ pasti akan meningkat tidak peduli apakah variabel independen tersebut terdapat hubungan secara signifikan terhadap variabel dependen. Tidak seperi $\mathrm{R}$, nilai adjusted $\mathrm{R}$ dapat naik atau turun apabila tambahan variabel independen ke dalam model.

\section{HASIL DAN PEMBAHASAN \\ Perilaku Pemimpin dan Komitmen Guru Pada MTs Negeri Terusan Kecamatan Muara Bulian Perilaku Pemimpin}

Perilaku pemimpin dapat terjadi karena seorang pemimpin untuk memperlakukan pengikutnya dalam upaya mempengaruhi perilaku bawahannya, maka pada 
bagian ini akan diuraikan hasil tanggapan responden berikut:

mengenai perilaku pemimpin yang diuraikan pada tabel

Tabel 1. Tanggapan Responden terhadap perilaku pemimpin pada MTs Negeri Terusan Kecamatan Muara Bulian.

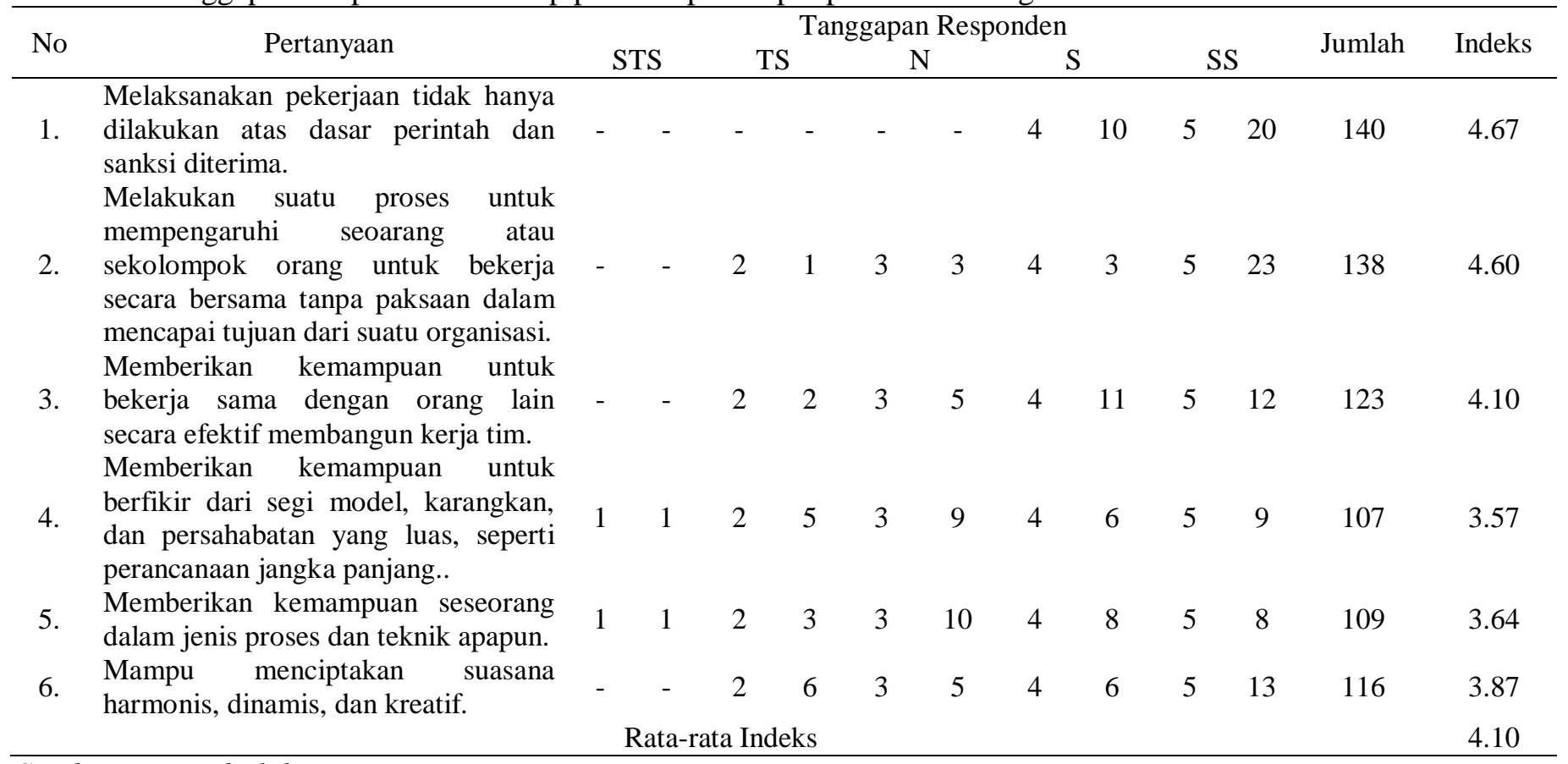

Sumber : Data diolah

Pada tabel 1 dapat diperoleh kesimpulan mengenai tanggapan responden terhadap Perilaku Pemimpin Pada MTs Negeri Terusan Kecamatan Muara Bulian yaitu dengan rata-rata indeks sebesar, ini berarti responden merasa Perilaku Pemimpin pada MTs Negeri Terusan Kecamatan Muara Bulian baik

\section{Komitmen Guru}

Komitmen Guru dapat terjadi karena adanya kekuatan bathin yang datang dari dalam hati seorang guru dan kekuatan dari luar itu sendiri tentang tugasnya yang dapat memberi pengaruh besar terhadap sikap guru berupa tanggung jawab dan responsive (inovatif) terhadap perkembangan ilmu pengetahuan dan teknologi, maka pada bagian ini akan diuraikan hasil tanggapan responden mengenai Komitmen Guru dapat diperoleh kesimpulan mengenai tanggapan responden terhadap pelaksanaan Komitmen Guru pada MTs Negeri Terusan Kecamatan Muara Bulian yaitu dengan rata-rata indeks sebesar, Ini berarti bahwa responden merasa bahwa Komitmen Guru pada MTs Negeri Terusan Kecamatan Muara Bulian baik.

\section{Tanggapan Responden terhadap Prestasi Kerja pada MTs Negeri Terusan Kecamatan Muara Bulian}

Untuk memperoleh gambaran tentang tanggapan responden terhadap prestasi kerja pada MTs Negeri Terusan Kecamatan Muara Bulian dapat diperoleh kesimpulan mengenai tanggapan responden terhadap prestasi kerja pada MTs Negeri Terusan Kecamatan Muara Bulian yaitu dengan rata-rata indeks Ini berarti bahwa prestasi kerja pada MTs Negeri Terusan Kecamatan Muara Bulian dianggap baik oleh para pegawai.

\section{Pengaruh Perilaku Pemimpin dan Komitmen Guru terhadap Prestasi Kerja Pada MTs Negeri Terusan Kecamatan Muara Bulain Uji Validitas}

Uji validitas ini dilakukan dengan membandingkan nilai yang didapat melalui perhitungan dengan bantuan program SPSS 20 dengan nilai pada tabel r. Berikut ini adalah hasil uji Validitas dalam penelitian ini

Tabel 2. Uji Variabel Perilaku Pemimpin

\begin{tabular}{ccccc}
\hline Variabel & Item pertanyaan & Product Moment $(\mathbf{r})$ & r Tabel & Keterngan \\
\hline & 1 & 0,707 & 0,3494 & Valid \\
Perilaku Pemimpin X1 & 2 & 0,644 & 0,3494 & Valid \\
& 3 & 0,721 & 0,3494 & Valid \\
& 4 & 0,605 & 0,3494 & Valid \\
& 5 & 0,754 & 0,3494 & Valid \\
\hline
\end{tabular}


Berdasarkan uji tabel diatas, dapat diketahui setiap variabel perilaku pemimpin secara keseluruhan bahwa semua item pertanyaan yang di uraikan pada dinyatakan valid untuk mendukung penelitian ini.

Tabel 3. Uji Variabel Komitmen Guru

\begin{tabular}{|c|c|c|c|c|}
\hline Variabel & Item pertanyaan & Product Moment (r) & r Tabel & Keterngan \\
\hline \multirow{6}{*}{ Komitmen Guru X2 } & 1 & 0,764 & 0,3494 & Valid \\
\hline & 2 & 0,655 & 0,3494 & Valid \\
\hline & 3 & 0,722 & 0,3494 & Valid \\
\hline & 4 & 0,692 & 0,3494 & Valid \\
\hline & 5 & 0.827 & 0,3494 & Valid \\
\hline & 6 & 0,728 & 0,3494 & Valid \\
\hline
\end{tabular}

\section{Sumber : Data Diolah}

Berdasarkan uji tabel diatas, dapat diketahui bahwa semua item pertanyaan yang di uraikan pada setiap variabel komitmen guru secara keseluruhan dinyatakan valid untuk mendukung penelitian ini.

Tabel 4. Uji Variabel Prestasi Kerja

\begin{tabular}{ccccc}
\hline Variabel & Item pertanyaan & Product Moment $(\mathbf{r})$ & r Tabel & Keterngan \\
\hline & 1 & 0,635 & 0,3494 & Valid \\
Prestasi Kerja Y & 2 & 0,624 & 0,3494 & Valid \\
& 3 & 0,733 & 0,3494 & Valid \\
& 4 & 0,774 & 0,3494 & Valid \\
& 5 & 0,735 & 0,3494 & Valid \\
& 6 & 0,647 & 0,3494 & Valid \\
\hline
\end{tabular}

\section{Sumber : Data Diolah}

Berdasarkan uji tabel diatas, dapat diketahui bahwa semua item pertanyaan yang di uraikan pada setiap variabel prestasi kerja secara keseluruhan dinyatakan valid untuk mendukung penelitian ini.

\section{Uji Reliabilitas}

Perhitungan pada uji reliabilitas ini juga menggunakan program SPSS 20. Hasil perhitungan lalu dibandingkan dengan tingkat signifikat sebesar $50 \%$ $(0,05)$

Tabel 5. Uji Reliabilitas

\begin{tabular}{llccc}
\hline No & Variabel Penelitian & Cronbach's Alpha & Tingkat Signifikansi & Keterangan \\
\hline 1 & Perilaku Pemimpin (X1) & 0,756 & 0,05 & Reliable \\
2 & Komitmen Guru (X2) & 0,823 & 0,05 & Reliable \\
3 & Prestasi Kerja (Y) & 0,781 & 0,05 & Reliable \\
\hline
\end{tabular}

\section{Sumber : Data Diolah}

Berdasarkan tabel diatas, dapat diketahui bahwa keseluruhan variabel memiliki nilai cronbach's alpha lebih besar $(>)$ dari tingkat signifikannya. Hal ini bahwa keseluruhan variabel dinyatakan reliabel untuk diterapkan dalam penelitian ini.

\section{Analisis Regresi Linear Berganda}

Dari hasil pengolahan dan diperoleh informasi pada tabel pengolahn SPSS 20 Di bawah ini :

Tabel 6. Tabel Output Koefisien Regresi Linear Berganda SPPS

\section{Coefficients}

\begin{tabular}{|c|c|c|c|c|c|}
\hline \multirow[b]{2}{*}{ Model } & \multicolumn{2}{|c|}{ Unstandardized Coefficients } & \multirow{2}{*}{$\frac{\text { Standardized Coefficients }}{\text { Beta }}$} & \multirow[b]{2}{*}{$\mathrm{T}$} & \multirow[b]{2}{*}{ Sig. } \\
\hline & $\mathrm{B}$ & Std. Error & & & \\
\hline (Constant) & 14.600 & 3.322 & & 4.395 & .000 \\
\hline Perilaku_Pemimpin & .526 & 246 & .508 & 2.139 & .042 \\
\hline Komitmen_Guru & -.405 & .234 & -.410 & -1.728 & .095 \\
\hline
\end{tabular}

a. Dependent Variable: Prestasi_Kerja

Dari tabel diatas, didapat nilai-nilai yang dapat kita tetapkan kedalam rumus rgresi berganda. Persamaan regresi berganda yang didapat adalah : $\mathrm{Y}=14,600+$ $0,525 \mathrm{X}_{1}+0,-405 \mathrm{X}_{2}$

\section{Uji-T dan Uji-F \\ Uji-T}


Dari hasil pengelohan pada tabel diatas, dapat diketahui bahwa nilai $\mathrm{t}$ hitung untuk variabel perilaku pemimpin sebesar 2,139 dan t hitung untuk variabel komitmen guru sebesar $-1,728$. sedangkan nilai $t$ tabel sebesar 2.05183. Berdasarkan hal tersebut, dapat ditarik kesimpulan bahwa :

1. Nilai $\mathrm{t}$ hitung variabel perilaku pemimpin $>\mathrm{t}$ tabel $(2,139>2.05183)$. Artinya terdapat pengaruh yang signifikan antara variabel perilaku pemimpin terhadap variabel prestasi kerja secara persial.
2. Nilai t hitung variabel komitmen guru $>\mathrm{t}$ tabel $(-$ $1,728>2.05183$ ). Artinya terdapat pengaruh yang signifikan antara variabel komitmen guru terhadap prestasi kerja secara persial.

\section{Uji-F}

Uji dilakukan dengan membandingkan nilai $\mathrm{f}$ hitung dengan nilai $\mathrm{f}$ tabel. Berikut tabel hasil perhitungan SPSS 20 untuk mengetahui nilai f hitung :

\begin{tabular}{|l|r|r|r|r|r|}
\hline Model & Sum of Squares & \multicolumn{1}{|c|}{ Df } & Mean Square & \multicolumn{1}{c|}{ F } & \multicolumn{1}{c|}{ Sig. } \\
\hline Regression & 59.245 & 2 & 29.623 & 2.372 & \\
Residual & 337.248 & 27 & 12.491 & & \\
Total & 396.493 & 29 & & & \\
\hline
\end{tabular}

a. Predictors: (Constant), Komitmen_Guru, Perilaku_Pemimpin

b. Dependent Variable: Prestasi_Kerja

Berdasarkan tabel diatas, diketahui bahwa nilai $\mathrm{f}$ hitung sebesar 2.372 dan nilai f tabel 3.34. Ini berarti bahwa nilai $\mathrm{f}$ hitung untuk variabel perilaku pemimpin dan variabel komitmen guru $>\mathrm{f}$ tabel $(2.372>3.34$ ). Ini berarti bahwa variabel perilaku pemimpin dan variabel komitmen guru mempengaruhi variabel prestasi kerja secara simultan (bersama-sama).

\section{Koefisien Determinasi $\left(R^{2}\right)$}

Untuk mengetahui nilai koefisien determinasi, dapat dilihat dari pengolahan data menggunakan SPSS 20 berikut ini.

Model Summary

\begin{tabular}{|l|r|r|r|r|}
\hline \multicolumn{1}{|c|}{ Model } & R & R Square & Adjusted R Square & Std. Error of the Estimate \\
\hline 1 & $.387^{\mathrm{a}}$ & .149 & .086 & 3.534 \\
\hline
\end{tabular}

a. Predictors: (Constant), Komitmen_Guru, Perilaku_Pemimpin

Dari tabel di atas dapat diketahui nilai Adjusted R2 sebesar 0,86. Ini berarti bahwa perilaku dan komitmen guru memberikan pengaruh sebesar 8,6\% terhadap prestasi kerja. Sedangkan $91,4 \%$ yang mempengaruhi prestasi kerja dipengaruhi oleh variabelvariabel lain yang tidak di teliti dalam penelitian ini.

\section{SIMPULAN}

Seluruh variabel yang diteliti valid dan relabel. Modal persamaan regresi yang didapat $\mathrm{Y}=14,600+$ $0,525 X_{1}+0,-405 X_{2}$, Masing-masing nilai t hitung t tiap variabel $\left(t_{\text {hitung }} X_{1}=2,139\right.$ dan $\left.t_{\text {hitung }} X_{2}=-1,728\right)$ pada Penelitian ini memenuhi syarat persial, karena nilai $t_{\text {hitung }}>$ nilai $t_{\text {tabel }}(n-k-1)$ sebesar 2,05183, artinya kedua variabel bebas Perilaku Pemimpin $\left(\mathrm{X}_{1}\right)$ ataupun Komitmen Guru $\left(\mathrm{X}_{2}\right)$ dapat bekerja secara tersendiri dalam mempengaruhi Prestasi Kerja (Y). Hasil uji F menunjukan kedua variabel dapat bekerja secara bersama-sama dimana $F_{\text {hitung }}=2.372>\mathrm{F}_{\text {tabel }}$ 3.34. Nilai adjusted $\mathrm{R}$ square menunjukan sebesar 0,86 atau $8,6 \%$. Hasil ini dapat diartikan bahwa kontribusi pengaruh yang diberikan dari kedua variabel bebas Perilaku Pemimpin (X1) dan Komitmen Guru (X2) terhadap Prestasi Kerja (Y) adalah sebesar 0,86\% sedangkan selebihnya sebesar $91,4 \%$ dipengaruhi oleh faktor lain yang tidak termasuk variabel penelitian.

\section{DAFTAR PUSTAKA}

Arikunto, Suharsimi. 2010. "Prosedur Penelitian". Jakarta : Penerbit PT Rineka Cipta.

Fachruddin Saudagar dan Ali Idrus. 2009. "Pengembangan Profesionalitas Guru". Jakarta : Penerbit Gaung Persada (GP Press).

Fahmi, Irham. 2013. "Manajemen Kepemimpinan Kepala Sekolah”. Yogyakarta : Penerbit ARRUZZ Media.

Riduwan. 2012. "Pengantar Statistika Sosial". Jakarta : Penerbit Alfabeta.

Sedarmayanti. 2011. "Manajemen Sumber Daya Manusia, Reformasi, Birokrasi dan Manajemen Pegawai Negeri Sipil”. Bandung : Penerbit PT Reflika Aditama.

Sutrisno, Edy. 2009. "Manajemen Sumber Daya Manusia". Jakarta : Penerbit Kencana Prenada Media Group.

Tjutju Yuniarsih dan Suwatno. 2009. "Manajemen Sumber Daya Manusia". Bandung : Penerbit Alfabeta 